\title{
Fuel properties, performance and emission characterization of waste cooking oil (WCO) in a variable compression ratio (VCR) diesel engine ${ }^{\S}$
}

\author{
Şafak Yıldızhan'”, Erinç Uludamar², Ahmet Çalık ${ }^{3}$, Gonca Dede $^{4}$, \\ Mustafa Özcanlı ${ }^{5}$ \\ 1,5Department of Automotive Engineering, Çukurova University, Turkey \\ 2,3 Department of Automotive Engineering, Adana Science and Technology University, Turkey \\ ${ }^{4}$ Department of Automotive Engineering, Amasya University, Turkey
}

\begin{abstract}
The current study investigates the fuel properties, performance and emission characteristics in a variable compression ratio (VCR) diesel of the biodiesel produced from the waste cooking oil (WCO). The WCO samples were collected from the university and converted to biodiesel fuel with a two-step transesterification reaction. The fuel property tests showed that the properties of the WCO biodiesel were within the biodiesel standards. Diesel, WCO biodiesel and diesel-WCO biodiesel blend (B20) was used as fuel in a VCR engine. The performance and emission characteristics of the engine were measured at two different compression ratios (14:1 and 16:1) under partial load conditions. The experimental results showed that WCO biodiesel slightly decreased the brake thermal efficiency and thus increased specific fuel consumption. Biodiesel usage improved $\mathrm{CO}$ emissions up to $21,75 \%$ compared to diesel fuel. But, biodiesel usage increased $\mathrm{CO}_{2}$ and $\mathrm{NO}_{\mathrm{x}}$ emission due to higher combustion temperature and extra oxygen content of the biodiesel.
\end{abstract}

Keywords: Compression ratio, Alcohol, Biodiesel, Performance, Emission

\section{INTRODUCTION}

Fossil fuels which are the main energy source for transportation of people and goods are depleting as it is known widely and the price of the fuel is increasing due to demand and supply facts [1]. Also, enviromental effects of the fossil fuels threaten the human heallt and nature of all world. The exhaust emissions of the internal combustion engines are formed by the combustion fuels and these gases include toxic pollutants such as carbon monoxide (CO), carbon dioxide $\left(\mathrm{CO}_{2}\right)$, oxides of nitrogen $\left(\mathrm{NO}_{\mathrm{x}}\right)$, unburned hydrocarbons $(\mathrm{UHC})$, sulphur dioxide $\left(\mathrm{SO}_{2}\right)$, and etc. These toxic gases are dangereosly harmful for human healt and the nature [2].

The known facts force researchers to look for alternative energy sources for internal combustion engines. Biodiesel, which can be derived from vegetable oils and animal fats has a potential of being a substitute since biodiesel fuels are less toxic and renewable [3]. Many raw materials have been studied by many researchers [1, 4-11]. Also, biodiesels are not significantly worse than fossil fuels in the means of engine performance. Biodiesels are mostly derived with transesterification reaction or thermal cracking methods. The main raw material of biodiesel are mostly non-edible vegetable oils, animal fats and waste oils. The necessity of large agricultural areas and the high effort for production of vegetable oils are one of the most important drawbacks of biodiesel usage. But, tonnes of oils are used all over the world for different purposes. Especially, the food industry produce a high amount of waste frying oil. The waste of food industries and even the waste oils used in the houses are hazardous for enviroment unless the wastes are managed properly. The trend of renewable processes have been started to spread recently. Even the local city corporations are aware of the huge amount of oil wastes and have some efforts on this particular subject. Recycle of waste materials is a popular research subject. Reproduction processes from the waste material are eco-friendly and economically useful since the raw materials are already used up and the unit reproduction cost can be pulled down of the original production cost in some cases.

In literature, there are many investigations on the production, performance, emission and combustion characteristics of biodiesels [12-19]. Hwang et al., (2016) published an article that investigates effects of biodiesel usage produced from

\footnotetext{
${ }^{*}$ Corresponding authour

Email: yildizhans@cu.edu.tr (Ş. Yıldızhan)

${ }^{\S}$ This paper was presented in the IMSEC-2016
} 
waste cooking oil on a compression ignition engine. The authors reported that waste cooking oil (WCO) biodiesel usage decreased the CO, hydrocarbon (HC) and smoke emissions, and also WCO biodiesel caused a slight decrement of in-cylinder pressure [20]. Man et al., (2016) reported a study that studies the effects of WCO-diesel blends on emission characteristics of a diesel engines. The study revealed that, WCO-diesel blend usage caused to increase of NOx emissions. But, CO, HC and particulate matter emisssion were decreased by WCO-diesel blends usage [21]. Piker et al., (2016) studied the on the biodiesel production from the waste oil bu using egg shells as catalyst. The authors reported that fatty acid methyl ester yield of $97 \mathrm{wt} . \%$ was obtained after $11 \mathrm{~h}$ at ambient temperature and pressure with egg shells [22]. In this study, fuel properties of waste cooking oil biodiesel and the effects of the biodiesel produced from waste frying oil that collected from the university on the performance and emission characteristics of a variable compression ratio (VCR) diesel engine were investigated.

\section{METHODOLOGY}

\subsection{Experimental Fuels}

The experimental study was conducted in Petroleum Research and Automotive Engineering Laboratories of the Department of Automotive Engineering at Çukurova University. Waste cooking oil (WCO) samples were used as raw material for biodiesel production. WCO biodiesel was produced with two-step transesterification reaction. First, the collected oil samples were filtered prior to reaction in order to clean the contaminants. The free fatty acid (FFA) value of the cleaned oil was measured with the standard titration method. The FFA of the WCO was measured as 1,93 wt. \%. Transesterification reaction was performed twice the FFA of WCO is high. The first reaction was performed at $65^{\circ} \mathrm{C}$ for 60 minutes by stirring. Methanol 20 wt. $\%$ and 0,5 wt. \% sodium hydroxide was used as reactant and catalyst, respectively. The methoxide was obtained before transesterification reaction by mixing methanol and sodium hydroxide. The second transesterification reaction was performed with methanol 10 wt. \% and 0,25 wt. \% sodium hydroxide under same conditions. After the reaction period, the mixture were batched in a separating funnel for 8 hours and at the end of the batching period the glycerine was separated from the mixture. After the separating the glycerine from the mixture, crude WCO biodiesel samples were obtained. Then, the crude biodiesel was washed with warm water and dried at $105^{\circ} \mathrm{C}$ for one hour. Finally, in order to purify and to refine biodiesel the crude biodiesel was filtered. The biodiesel production flow diagram was shown in Figure 1.

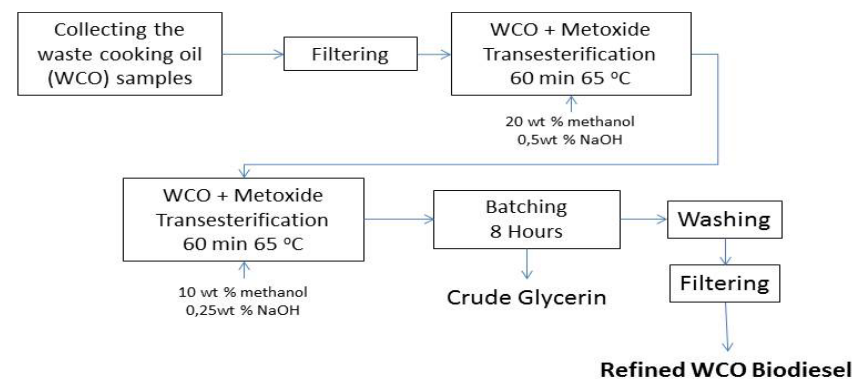

Figure 1: Biodiesel production flow diagram

In the study, low sulphur diesel fuel (conventional diesel), WCO biodiesel (waste cooking oil methyl ester), diesel-biodiesel blend B20 (80\% diesel + 20\% WCO) were used as fuel in a variable compression ratio (VCR) diesel engine in order to investigate the effects of waste cooking oil biodiesel on the performance and emission characteristics of a VCR diesel engine at different compression ratios.

The psychical properties of the test fuels were measured before testing them in the test engine. Instruments used for analysing the products were; Zeltex ZX 440 NIR petroleum analyser with an accuracy of \pm 0.5 for determining cetane number; Tanaka AFP-102 for cold filter plugging point; Tanaka AKV-202 Auto Kinematic Viscosity test for determining the viscosity; Kyoto electronics DA-130 for density measurement, Tanaka flash point control unit FC-7 for flash point determination and IKA Werke C2000 bomb calorimeter for determination of heating value. The fuel quality measurements were performed according to EN 14214 and EN 590.

\subsection{Experimental Setup}

The performance and emission measurements were performed with a single cylinder, multi fuel, and variable compression ratio diesel engine. In order to provide the accuracy of measurements, the experiments were done at partial load conditions (60\% load). An eddy current dynamometer was used to measure performance characteristics of the engine. Brake thermal efficiency (BTHE), specific fuel consumption (SFC) and exhaust gas temperature (EGT) results of the engine for test fuels were studied at two different compression ratios (14:1 and 16:1). Also, the exhaust emissions of 
the engine were measured simultaneously. Carbon monoxide $(\mathrm{CO})$, carbon dioxide $\left(\mathrm{CO}_{2}\right)$, and nitrogen oxides $\left(\mathrm{NO}_{\mathrm{x}}\right)$ emissions were studied for all test fuels. Table 1 and 2 shows the technical specifications of the VCR test engine and exhaust gas analyser.

Table 1 Technical specifications of the test engine

\begin{tabular}{|c|c|}
\hline Brand & Kirloskar Oil Engines \\
\hline Model & 240 \\
\hline Configuration & Single Cylinder \\
\hline Type & Four Stroke, Water Cooled \\
\hline Displacement & $661 \mathrm{cc}$ \\
\hline Bore & $87.5 \mathrm{~mm}$ \\
\hline Stroke & $110 \mathrm{~mm}$ \\
\hline $\begin{array}{c}\text { Maximum/Minimum Opera- } \\
\text { ting Speed }\end{array}$ & $2000 / 1200 \mathrm{rpm}$ \\
\hline Power & $3.5 \mathrm{Kw} @ 1500 \mathrm{rpm}$ \\
\hline CR range & $12: 1-18: 1$ \\
\hline Injection Variation & $0-25$ Deg BTDC \\
\hline Peak Pressure & $77.5 \mathrm{~kg} / \mathrm{cm} 2$ \\
\hline Air cleaner & Paper element type \\
\hline Weight & $160 \mathrm{~kg}$ \\
\hline Combustion Principle & Compression Ignition \\
\hline Lubricating System & Forced Feed System \\
\hline
\end{tabular}

Table 2 Technical specifications of the emission device

\begin{tabular}{|c|c|}
\hline Brand & MRU Air Delta $1600 \mathrm{~V}$ \\
\hline $\mathrm{CO}$ & $0-10 \%$ \\
\hline $\mathrm{CO} 2$ & $0-20 \%$ \\
\hline $\mathrm{HC}$ & $0-20000 \mathrm{ppm}$ \\
\hline $\mathrm{O} 2$ & $0-22 \%$ \\
\hline $\mathrm{NO}$ & $0-4000 \mathrm{ppm}$ \\
\hline $\mathrm{NO} 2$ & $0-1000 \mathrm{ppm}$ \\
\hline Lambda & $0-9.99$ \\
\hline Accuracy & According to OIML-class 1 \\
\hline Ambient Temperature & $+5 \mathrm{o}-+45 \mathrm{oC}$ \\
\hline Exhaust Gas Temperature & Max 650 oC \\
\hline
\end{tabular}

\section{RESULTS AND DISCUSSIONS}

\subsection{Fuel Properties}

Some important physical fuel properties test fuels were measured. The fuel properties of the diesel, WCO and B20 fuel were given in table 3. Fuel property tests shows that density of WCO and B20 was higher than the diesel fuel, but the values were within the biodiesel standards EN 14214. The tests showed that WCO biodiesel has a higher kinematic viscosity than diesel fuel. High viscosity can damage fuel pump but, the viscosity of WCO biodiesel and B20 were within the standards and it can be used directly without any modification. Heating value of the WCO biodiesel and B20 was slightly lower than diesel fuel. Flash point of the WCO biodiesel was over $120^{\circ} \mathrm{C}$ which is safer compared to diesel fuel. Also, blending WCO biodiesel with diesel fuel increased the flash point value of the diesel fuel which is an important criteria for storage of the fuel. Cold filter plugging point of the WCO was measured higher than diesel fuel.

Table 4 Fuel properties of test fuels

\begin{tabular}{|c|c|c|c|c|c|}
\hline & \multicolumn{5}{|c|}{ Test Fuels } \\
\hline Fuel Properties & Diesel & EN590 & WCO Biodiesel & B20 & EN 14214 \\
\hline Density $\left(20^{\circ} \mathrm{C}\right) \mathrm{kg} / \mathrm{m}^{3}$ & 837 & $820-845$ & 889 & 847 & $860-900$ \\
\hline Cetane Number & 59,47 & Min 51 & 51,62 & 53 & Min 51 \\
\hline $\mathrm{CFPP}{ }^{\circ} \mathrm{C}$ & -11 & - & -5 & -10 & $\begin{array}{c}\text { Summer }<4 \\
\text { Winter }<1\end{array}$ \\
\hline Heating Value, $\mathrm{MJ} / \mathrm{kg}$ & 45,856 & - & 39,48 & 44,32 & - \\
\hline $\begin{array}{c}\text { Kinematic Viscosity }\left(40^{\circ} \mathrm{C}\right) \\
\mathrm{mm}^{2} / \mathrm{s}\end{array}$ & 2,76 & $2,0-4,5$ & 4,75 & 3,18 & $3.5-5.0$ \\
\hline Flash Point ${ }^{\circ} \mathrm{C}$ & 79.5 & Min 55 & $>120$ & 93 & Min 120 \\
\hline
\end{tabular}




\subsection{Performance Characteristics}

Brake thermal efficiency (BTHE) can be defined as the ratio of power output to heat input. BTHE values are also related with heating value of the fuels. Higher BTHE value indicates the better combustion of fuel which means higher cylinder pressure and higher power output for unit fuel used. Specific fuel consumption (SFC) is a measure of how efficiently fuel is used and this value is directly related with BTHE [23]. Figure 2 and 3 shows the BTHE and SFC results of test fuels. It can be seen from the graphs increasing CR from 14:1 to 16:1 increased BTHE and decreased SFC values for all test fuels due to better combustion of fuels. Increasing CR from 14:1 16:1 increased BTHE values 2,29\%, 6,75\%, and 2,37\% for diesel fuel, WCO biodiesel and B20 fuel, respectively. Higher compression ratio experiments resulted in 7,06\%, 10,13\%, and 9,92\% lower SFC for diesel fuel, WCO biodiesel, and B20 fuel respectively. WCO biodiesel usage slightly decreased BTHE values compared to diesel fuel. BTHE results of WCO biodiesel were 8,62\% and 4,64\% lower compared to diesel fuel, at 14:1 and 16:1 compression ratios, respectively. Exhaust gas temperature (EGT) is an important criteria for internal combustion engines and it is related with combustion parameters such as compression ratio and fuel properties [24]. EGT results are shown in Figure 4. It can be seen from the graph WCO usage increased EGT compared to diesel fuel due to higher oxygen content of biodiesel. Also, increasing compression ratio increased EGT significantly for all test fuels.

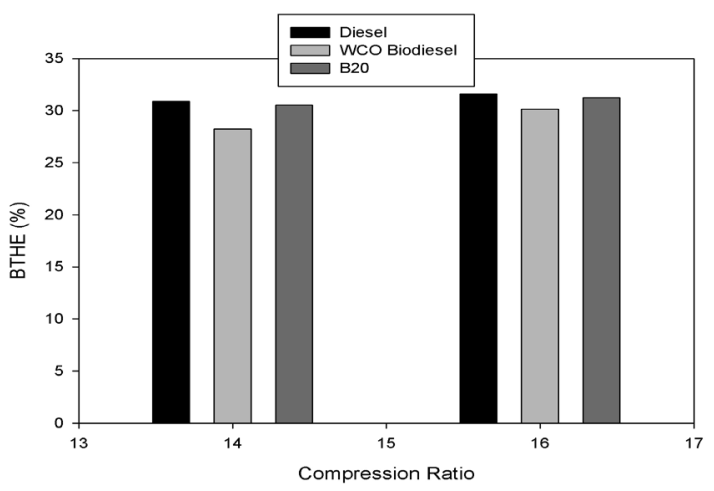

Figure 2: Brake thermal efficiency results

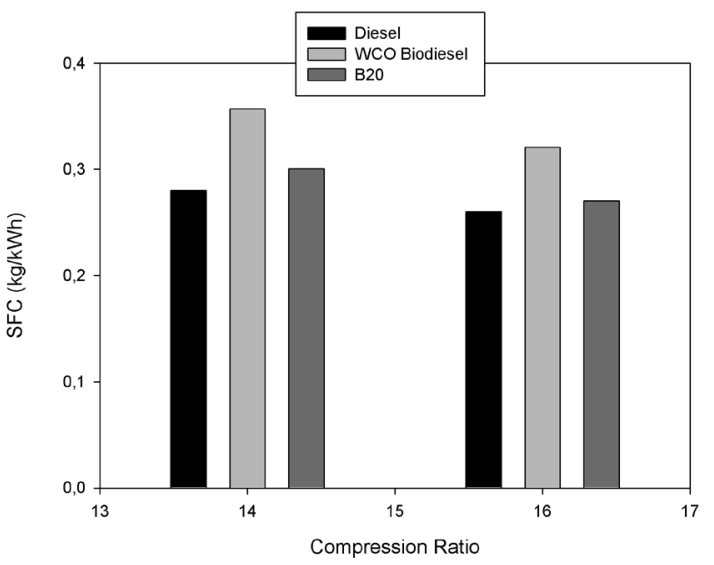

Figure 3: Specific fuel consumption results

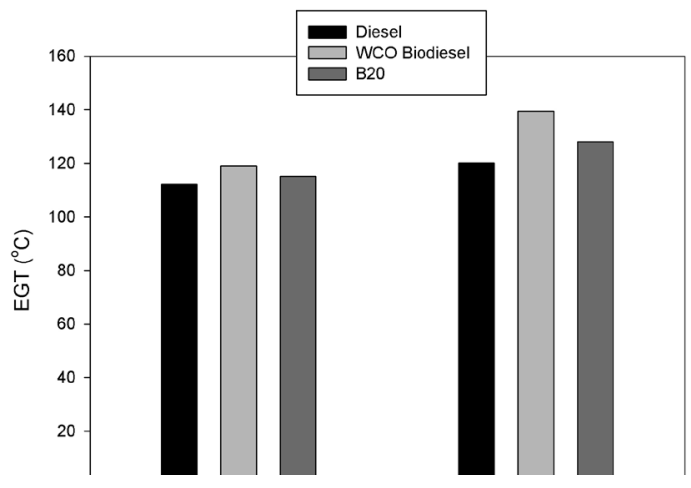

Figure 4: Exhaust gas temperature results 


\subsection{Emission Characteristics}

Throughout the study; $\mathrm{CO}, \mathrm{CO}_{2}$ and $\mathrm{NO}_{x}$ emissions of the test engine were measured. Figure 5, 6 and 7 shows the $\mathrm{CO}, \mathrm{CO}_{2}$ and $\mathrm{NO}_{x}$ results of all test fuels, respectively. The study showed that increasing CR improved CO emissions for all test fuels due to better combustion of fuels [25]. But, $\mathrm{CO}_{2}$ and $\mathrm{NO}_{\mathrm{x}}$ emissions were increased when compression ratio was elevated. Higher compression ratios enhance the combustion and thus nitrogen oxides emissions significantly elevates due to higher in-cylinder temperature and higher flame velocity. Biodiesel usage usually improves CO emissions and increases $\mathrm{CO}_{2}$ and $\mathrm{NO}_{\mathrm{x}}$ emissions due to higher combustion temperature and extra oxygen content in the chemical composition [26].

Increasing CR from 14:1 to 16:1 improved CO values 34,42\%, 42,03\% and 34,63\% for diesel fuel, WCO biodiesel and B20 fuel, respectively. But, increasing compression ratio increased $\mathrm{CO}_{2}$ values 9,41\%, 15,18\%, and 9,40\% for diesel fuel, WCO biodiesel and B20 fuel, respectively. Also, 16:1 compression ratio experiments resulted in 4,83\%, 12,5\%, and 9,19\% higher $\mathrm{NO}_{\mathrm{x}}$ for diesel fuel, WCO biodiesel, and B20 fuel, respectively. Biodiesel usage improved CO emissions $11,47 \%$ and $21,75 \%$ for $14: 1$ and 16:1 compression ratios, respectively, compared to diesel fuel. But in contrary, biodiesel usage increased $\mathrm{CO}_{2}$ and $\mathrm{NO}_{x}$ emissions compared to diesel fuel for both compression ratios. WCO biodiesel increased $\mathrm{CO}_{2}$ emissions 10,56\%, and 16,39\% compared to diesel fuel for 14:1 and 16:1 compression ratios, respectively. Also, WCO biodiesel increased $\mathrm{NO}_{\mathrm{x}}$ emissions 40\%, and 50,23\% compared to diesel fuel for 14:1 and 16:1 compression ratios, respectively.

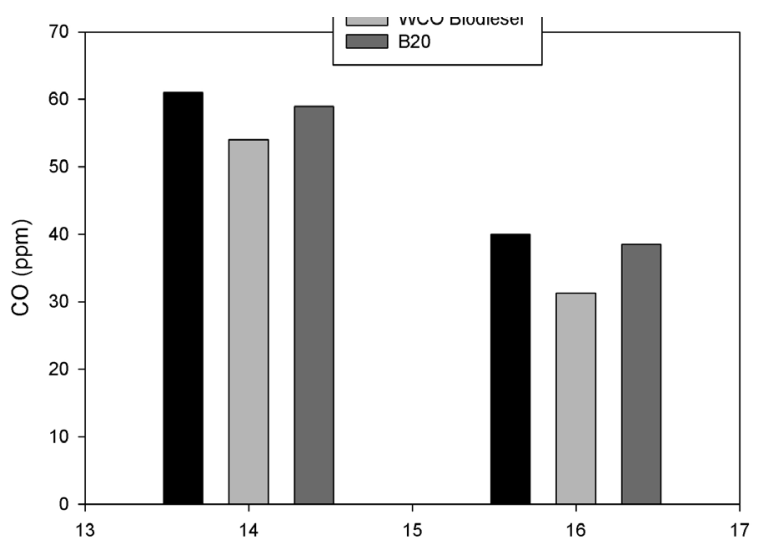

Figure 5: $\mathrm{CO}$ emission results

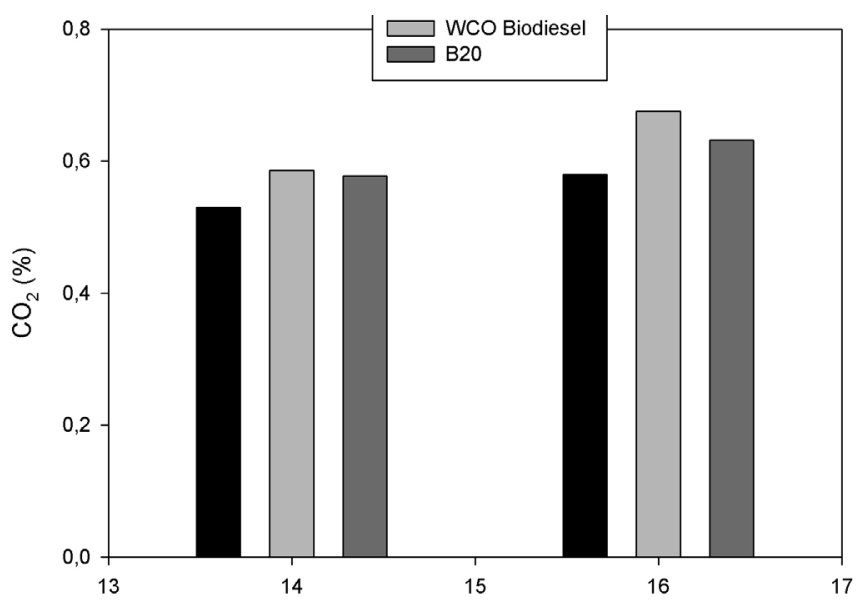

Figure 6: $\mathrm{CO} 2$ emission results 


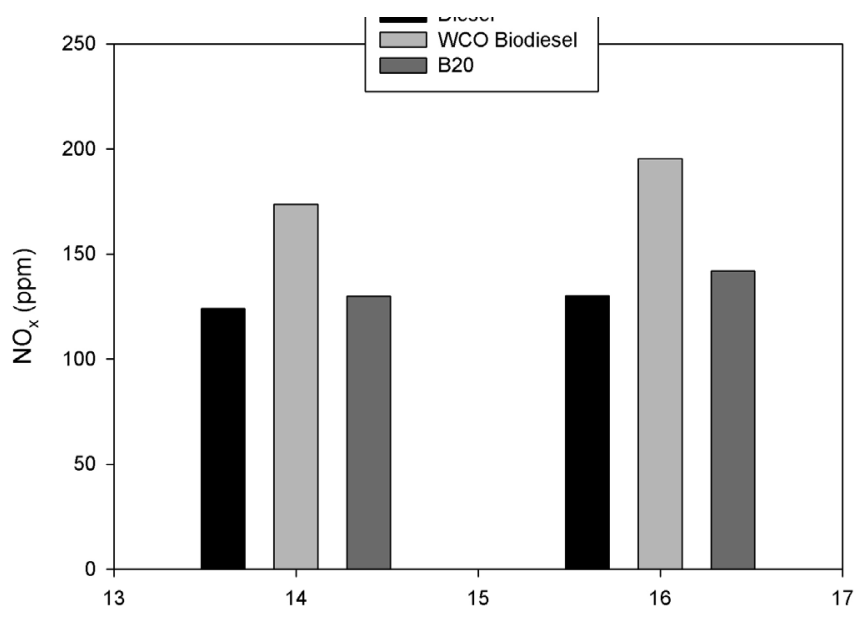

\section{CONCLUSIONS}

Figure 7: $\mathrm{NO}_{\mathrm{x}}$ emission results

In this study waste cooking oil was converted to biodiesel by using transesterification reaction and the effects of diesel, waste cooking biodiesel and diesel-biodiesel blend usages were investigated at two different compression ratios in a variable compression ratio diesel engine. Throughout the study following conclusions were obtained;

- Waste cooking oil has a high FFA value and thus two-step transesterification was performed.

- Fuel properties of waste cooking oil and its blend with diesel fuel were within the biodiesel standards.

- Increasing compression ratio improved BTHE and SFC values, and increased EGT for all test fuels.

- Increasing compression ratio improved $\mathrm{CO}$ emissions but caused to increase of $\mathrm{CO}_{2}$ emissions and $\mathrm{NO}_{\mathrm{x}}$ emissions.

- Waste cooking oil biodiesel usage slightly decreased BTHE and SFC values and increased EGT.

- Waste cooking oil usage improved $\mathrm{CO}$ emissions and caused to increase of $\mathrm{CO}_{2}$ emissions and $\mathrm{NO}_{\mathrm{x}}$ emissions.

\section{ACKNOWLEDGEMENTS}

The authors would like to thank the Cukurova University Scientific Research Project Coordination (FBA-2016-5509) for financial support to this project.

\section{REFERENCES}

[1] Tüccar, G., Tosun, E., Özgür, T., and Aydın, K. (2014). Diesel engine emissions and performance from blends of citrus sinensis biodiesel and diesel fuel. Fuel, vol. 132, pp. 7-11. 10.1016/j.fuel.2014.04.065

[2] Sajjadi, B., Raman, A.A.A., and Arandiyan, H. (2016). A comprehensive review on properties of edible and non-edible vegetable oil-based biodiesel: Composition, specifications and prediction models. Renewable and Sustainable Energy Reviews, vol. 63, pp. 62-92. 10.1016/j.rser.2016.05.035

[3] Ramkumar, S. and Kirubakaran, V. (2016). Biodiesel from vegetable oil as alternate fuel for C.I engine and feasibility study of thermal cracking: A critical review. Energy Conversion and Management, vol. 118, pp. 155-169. 10.1016/j.enconman.2016.03.071

[4] Akar, M.A. (2016). Performance and emission characteristics of compression ignition engine operating with false flax biodiesel and butanol blends. Advances in Mechanical Engineering, vol. 8, no. 2, pp. 1-7. 10.1177/1687814016632677

[5] Farooq, M., Ramli, A., and Naeem, A. (2015). Biodiesel production from low FFA waste cooking oil using heterogeneous catalyst derived from chicken bones. Renewable Energy, vol. 76, pp. 362-368. 10.1016/j.renene.2014.11.042

[6] Iglesias, L., Laca, A., Herrero, M., and Díaz, M. (2012). A life cycle assessment comparison between centralized and decentralized biodiesel production from raw sunflower oil and waste cooking oils. Journal of Cleaner Production, vol. 37, pp. 162-171. 10.1016/j.jclepro.2012.07.002

[7] Issariyakul, T. and Dalai, A.K. (2010). Biodiesel Production from Greenseed Canola Oil. Energy \& Fuels, vol. 24, no. 9, pp. 4652-4658. 10.1021/ef901202b

[8] Predojevic, Z., Skrbic, B., and Djurisic-Mladenovic, N. (2012). Transesterification of linoleic and oleic sunflower oils to biodiesel using $\mathrm{CaO}$ as a solid base catalyst. Journal of the Serbian Chemical Society, vol. 77, no. 6, pp. 815-832. https://doi.org/10.2298/JSC110824206P 
[9] Sootchiewcharn, N., Attanatho, L., and Reubroycharoen, P. (2015). Biodiesel Production from Refined Palm Oil using Supercritical Ethyl Acetate in A Microreactor. Energy Procedia, vol. 79, pp. 697-703. 10.1016/j.egypro.2015.11.560

[10] Witoon, T., Bumrungsalee, S., Vathavanichkul, P., Palitsakun, S., Saisriyoot, M., and Faungnawakij, K. (2014). Biodiesel production from transesterification of palm oil with methanol over $\mathrm{CaO}$ supported on bimodal meso-macroporous silica catalyst. Bioresource Technology, vol. 156, pp. 329-334. 10.1016/j.biortech.2014.01.076

[11] Yücel, Y. (2011). Biodiesel production from pomace oil by using lipase immobilized onto olive pomace. Bioresource Technology, vol. 102, no. 4, pp. 3977-3980. 10.1016/j.biortech.2010.12.001

[12] Ozcanli, M., Akar, M.A., Calik, A., and Serin, H. (2017). Using HHO (Hydroxy) and hydrogen enriched castor oil biodiesel in compression ignition engine. International Journal of Hydrogen Energy. 10.1016/j.ijhydene.2017.01.091

[13] Serin, H., Yildizhan, S., Akar, M.A., and Ozcanli, M. (2016). Methodological effects of thermal cracking and transesterification on fuel specifications of false flax biodiesel. Journal of Biotechnology, vol. 231, p. S47. 10.1016/j.jbiotec.2016.05.179

[14] Serin, H. and Akar, N.Y. (2013). The Performance and Emissions of a Diesel Engine Fueled with Tea Seed (Camellia sinensis) Oil Biodiesel-Diesel Fuel Blends. International Journal of Green Energy, vol. 11, no. 3, pp. 292-301. $10.1080 / 15435075.2013 .773434$

[15] Serin, H., Ozgur, C., Ozcanli, M., Aydin, K., and Ozgur, T. (2013). Preparation of fuels by cracking of different plastics and their blends with diesel fuel. Current Opinion in Biotechnology, vol. 24, p. S44. 10.1016/j.copbio.2013.05.097

[16] Tosun, E., Ozgur, T., Ozgur C., Ozcanli, M., Serin, H., Aydin, K. (2017). Comparative analysis of various modelling techniques for emission prediction of diesel engine fueled by diesel fuel with nanoparticle additives. European Mechanical Science vol. 1, no. 1, pp. 15-23.

[17] Özcanli, M., Serin, H., Saribiyik, O.Y., Aydin, K., and Serin, S. (2012). Performance and Emission Studies of Castor Bean (Ricinus Communis) Oil Biodiesel and Its Blends with Diesel Fuel. Energy Sources, Part A: Recovery, Utilization, and Environmental Effects, vol. 34, no. 19, pp. 1808-1814. 10.1080/15567036.2010.545800

[18] Çelebi, K., Uludamar, E., and Özcanl, M. (2017). Evaluation of fuel consumption and vibration characteristic of a compression ignition engine fuelled with high viscosity biodiesel and hydrogen addition. International Journal of Hydrogen Energy, https://doi.org/10.1016/j.ijhydene.2017.02.066

[19] Sarıbıyık, O.Y., Özcanlı, M., Serin, H., Serin, S., and Aydın, K. (2011). Biodiesel Production from Ricinus Communis Oil and its Blends with Soybean Biodiesel. Strojniški vestnik - Journal of Mechanical Engineering, 10.5545/sv-jme.2009.054

[20] Hwang, J., Bae, C., and Gupta, T. (2016). Application of waste cooking oil (WCO) biodiesel in a compression ignition engine. Fuel, vol. 176, pp. 20-31. 10.1016/j.fuel.2016.02.058

[21] Man, X.J., Cheung, C.S., Ning, Z., Wei, L., and Huang, Z.H. (2016). Influence of engine load and speed on regulated and unregulated emissions of a diesel engine fueled with diesel fuel blended with waste cooking oil biodiesel. Fuel, vol. 180, pp. 41-49. 10.1016/j.fuel.2016.04.007

[22] Piker, A., Tabah, B., Perkas, N., and Gedanken, A. (2016). A green and low-cost room temperature biodiesel production method from waste oil using egg shells as catalyst. Fuel, vol. 182, pp. 34-41. 10.1016/j.fuel.2016.05.078

[23] Amarnath, H.K., Prabhakaran, P., Bhat, S.A., and Paatil, R. (2014). A Comparative Analysis of Thermal Performance And Emission Characteristics of Methyl Esters of Karanja And Jatropha Oils Based on A Variable Compression Ratio Diesel Engine. International Journal of Green Energy, vol. 11, no. 7, pp. 675-694. 10.1080/15435075.2013.777905

[24] Mohanraj, T. and Mohan Kumar, K.M. (2013). Operating Characteristics of a Variable Compression Ratio Engine Using Esterified Tamanu Oil. International Journal of Green Energy, vol. 10, no. 3, pp. 285-301. 10.1080/15435075.2011.653849

[25] Vasudeva, M., Sharma, S., Mohapatra, S.K., and Kundu, K. (2016). Performance and exhaust emission characteristics of variable compression ratio diesel engine fuelled with esters of crude rice bran oil. SpringerPlus, journal article vol. 5, no. 1, p. 293. $10.1186 / s 40064-016-1945-7$

[26] Chavan, S.B., Kumbhar, R.R., Kumar, A., and Sharma, Y.C. (2015). Study of Biodiesel Blends on Emission and Performance Characterization of a Variable Compression Ratio Engine. Energy \& Fuels, vol. 29, no. 7, pp. 4393-4398. 10.1021/acs.energyfuels.5b00742 